\title{
DEGRADATION OF PYRIMIDINE NUCLEOTIDES BY ENZYME SYSTEMS OF STREPTOMYCES
}

\section{PYRIMIDINE $5^{\prime}$-NUCLEOTIDE PHOSPHORIBO (DEOXYRIBO) HYDROLASE OF STREPTOMYCES VIRGINIAE}

\author{
AKIRA IMADA \\ Microbiological Research Laboratories, Research and Development Division, \\ Takeda Chemical Industries, Ltd., Osaka, Japan
}

(Received June 13, 1967)

\begin{abstract}
A novel enzyme, pyrimidine 5'-nucleotide phosphoribo (deoxyribo) hydrolase, which hydrolyzes the $\mathrm{N}$-glycosidic linkage in pyrimidine $5^{\prime}$ nucleotides to pyrimidine bases and pentose-5-phosphates, was extracted and purified to about 31-fold from the cells of Streptomyces virginiae and its properties were examined.

The purified enzyme hydro!yzed $5^{\prime}$-UMP, 5'-CMP, 5'-deoxyUMP, $5^{\prime}$ deoxyTMP and 5'-deoxyCMP. Purine $5^{\prime}$-nucleotides were degraded by the crude extracts, but this activity was removed by the purification. Nucleosides and $3^{\prime}$-nucleotides of purines and pyrimidines were never cleaved even by the crude extracts. $2^{\prime}$-O-methyl-5'-UMP was also resistant to the enzyme reaction.

The $K_{m}$ value for $5^{\prime}$-UMP was $6.95 \times 10^{-3} \mathrm{M}$. Co-factors of low molecular weight were unnecessary for the reaction. Phosphate, pyrophosphate and ATP had little stimulatory effect on the reaction. The enzyme was relatively heat stable between $\mathrm{pH} 5.5$ and 8.8 . The activity remained unaffected after heating the enzyme solution at $65^{\circ}$ for $45 \mathrm{~min}$. $\mathrm{Ca}^{++}$had a marked stabilizing effect on the enzyme.
\end{abstract}

This report is concerned with partial purification and properties of a pyrimidine 5'-nucleotide-degrading enzyme from Streptomyces virginiae which shall be called pyrimidine $5^{\prime}$-nucleotide phosphoribo (deoxyribo) hydrolase.

Distribution of the enzyme, products of the reaction and some conditions of $5^{\prime}$-UMP degradation have been reported in the preceding paper (1).

\section{MATERIALS AND METHODS}

Reagents. Ribose-1-phosphate was prepared from uridine by uridine phosphorylase of Pseudomonas putrefaciens IFO 3910 and its cyclohexylamine salt was obtained according to the method of PLESNER and KLENOw (2). 5Phosphoribosyl-1-pyrophosphate was purchased from Sigma Chemical Company. 
Ba-salt of ribose-5-phosphate was obtained from Nutritional Biochemicals Corp. 2'-O-methyl-5'-UMP was supplied by Dr. Honjo of our laboratories. Sources of other reagents have been reported elsewhere (3).

Enzyme extraction. Streptomyces virginiae IFO 3729 was cultured and crude extracts were prepared as described previously (1).

EDTA-treatment. The crude extracts were mixed with EDTA of a final concentration of $5 \mathrm{~mm}$ in a dialyzing tube. The mixture was stood for $10 \mathrm{~min}$ at $4^{\circ}$, then the tube was dialyzed against running desalted water for $2 \mathrm{hr}$ at $24^{\circ}$ followed by dialysis against several changes of distilled water at $4^{\circ}$ for $18 \mathrm{hr}$. This dialyzed solution was designated as "EDTA-treated enzyme".

Assay of enzyme activity. The assay is based on an increase of molecular extinction coefficient at $290 \mathrm{~m} \mu$ in an alkaline $\mathrm{pH}$ upon conversion of $5^{\prime}$-UMP to uracil (1). The test system contained $20 \mu$ moles of $5^{\prime}$-UMP, $100 \mu$ moles of acetate buffer ( $\mathrm{pH} \quad 6.0)$ and 2.5 to 12.5 units of the enzyme in a total volume of $1.0 \mathrm{ml}$. The mixture was incubated at $55^{\circ}$ for $1 \mathrm{hr}$ and the reaction was stopped by heating the mixture in a boiling water bath for $5 \mathrm{~min}$. This solution was diluted in $0.2 \mathrm{~N} \mathrm{NaOH}$ and the optical density at $290 \mathrm{~m} \mu$ was measured with a Beckman DU spectrophotometer. The blank tests were run without $5^{\prime}$-UMP, which was added after the reaction was stopped.

A unit of the enzyme was defined as the amount causing the formation of $1 \mu$ mole uracil in $1 \mathrm{hr}$. The specific activity was defined as units of enzyme per $\mathrm{mg}$ of protein.

Under the conditions of the assay, the rate of uracil formation was proportional to the amount of enzyme.

Other determinations. Pentose was estimated by the orcinol reaction (4) using ribose-5-phosphate as standard. Reducing sugar was determined by Somogyi's method (5) using D-ribose and 2-deoxy-D-ribose as standards. Protein and phosphate were estimated as previously described $(6)$. Formation of cytosine from $5^{\prime}$-CMP was determined by a decrease $\left(4.50 \times 10^{3}\right)$ of molecular extinction coefficient at $250 \mathrm{~m} \mu$ in $0.2 \mathrm{~N} \mathrm{NaOH}$.

Paper electrophoresis of nucleic acid components were carried out as described previously (1).

\section{RESULTS}

\section{Purification of enzyme}

Cells of Streptomyces virginiae were harvested from $1,630 \mathrm{ml}$ of 4-day culture broth and suspended in $320 \mathrm{ml}$ of distilled water and sonicated at 10 kc. for $10 \mathrm{~min}$. The sonicate was centrifuged at $37,000 \times g$ for $1 \mathrm{hr}$. To 300 $\mathrm{ml}$ of the supernatant fluid, $6 \mathrm{ml}$ of $100 \mathrm{mM} \mathrm{CaCl}_{2}$ and $6 \mathrm{ml}$ of $1 \mathrm{M}$ acetate buffer ( $\mathrm{pH} 6.0$ ) were added. Then the mixture was heated at $55^{\circ}$ for $1 \mathrm{hr}$ and centrifuged at $27,000 \times g$ for $1 \mathrm{hr}$. Twenty $\mathrm{ml}$ of $10 \%$ solution of streptomycin sulfate was added to $300 \mathrm{ml}$ of the supernatant fluid. Massive precipi- 
Table 1. Summary of the purification of the enzyme.

\begin{tabular}{|c|c|c|c|c|c|c|}
\hline Fraction & $\begin{array}{l}\text { Volume } \\
(\mathrm{ml})\end{array}$ & $\begin{array}{l}\text { Protein } \\
(\mathrm{mg} / \mathrm{ml})\end{array}$ & $\begin{array}{l}\text { Activity } \\
\text { (units/ml) }\end{array}$ & $\begin{array}{l}\text { Specific } \\
\text { activity } \\
\text { (units } \\
\text { per mg } \\
\text { protein) }\end{array}$ & $\begin{array}{c}\text { Total } \\
\text { activity } \\
\text { (units) }\end{array}$ & $\begin{array}{l}\text { Recovery } \\
(\%)\end{array}$ \\
\hline Crude extracts & 300 & 5.75 & 39.0 & 6.78 & 11700 & 100.0 \\
\hline Heat treated & 310 & 4.55 & 35.2 & 7.74 & 10900 & 93.1 \\
\hline $\begin{array}{l}\text { Streptomycin } \\
\text { treated }\end{array}$ & 330 & - & 28.8 & - & 9500 & 81.2 \\
\hline $\begin{array}{c}\text { Ammonium sulfate } \\
\text { fraction }\end{array}$ & 11.1 & 22.0 & 908.0 & 41.3 & 10080 & 86.1 \\
\hline Sephadex fraction & 20.0 & 0.7 & 147.0 & 210.0 & 2940 & 25.1 \\
\hline
\end{tabular}

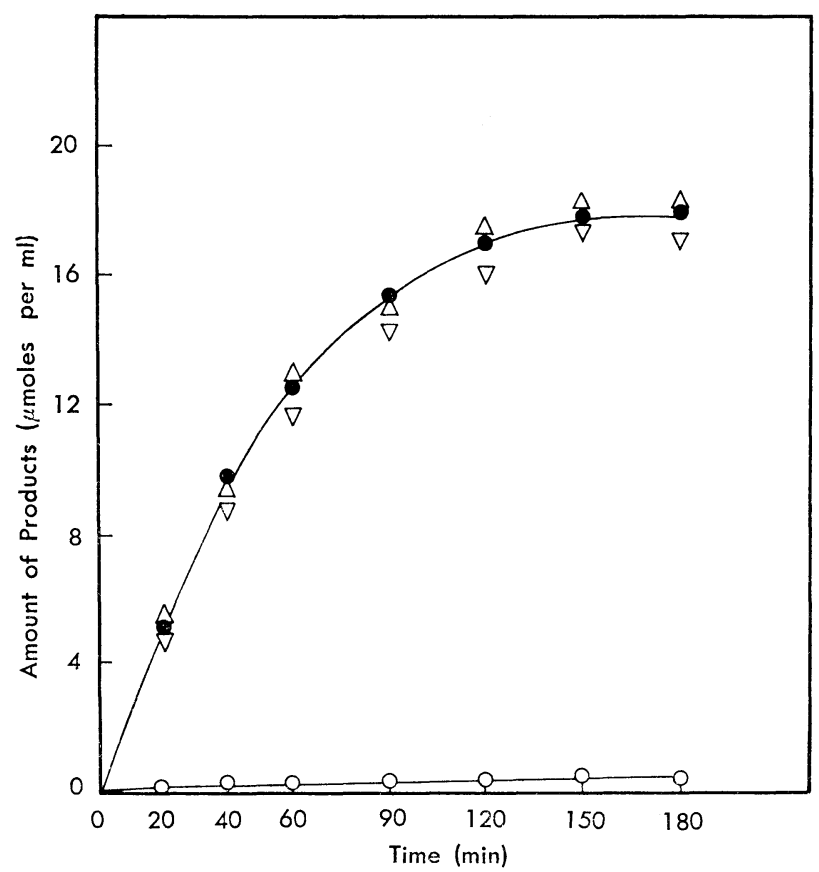

Fig. 1. Time course of $5^{\prime}$-UMP degradation.

The assay system described in text containing 11.9 units of purified enzyme was incubated at $55^{\circ}$.

- - Formation of uracil $\quad-\triangle-$ Formation of pentose

$-\nabla-$ Formation of reducing sugar $\quad-\bigcirc-$ Formation of inorganic phosphate 

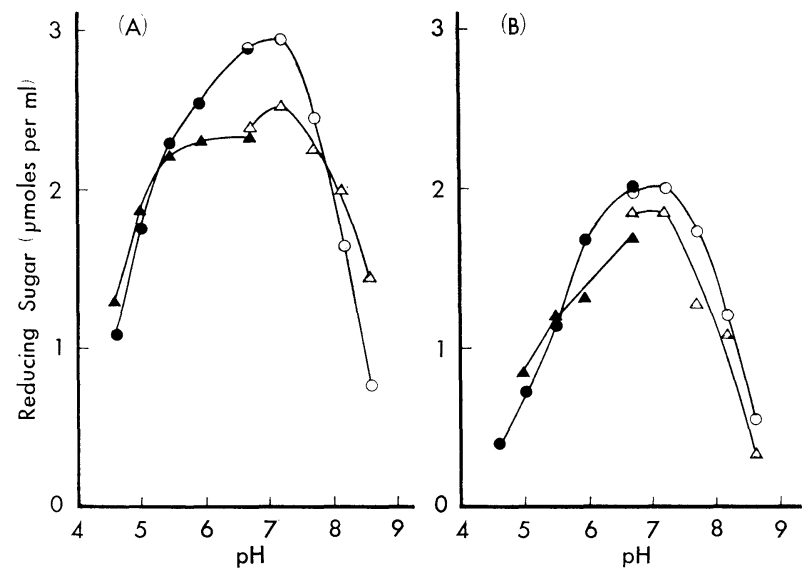
tides.

Fig. 2. Effect of $\mathrm{pH}$ on the degradation of pyrimidine $5^{\prime}$-nucleo-

One $\mathrm{ml}$ of the reaction mixture containing $500 \mu$ moles of acetate buffer $(-\boldsymbol{\Delta}-)$ or Tris buffer $(-\mathrm{O}-\triangle-), 1 \mu$ mole of $\mathrm{CaCl}_{2}, 10 \mu$ moles of $5^{\prime}$-UMP, 5'-CMP, 5'-deoxyUMP or $5^{\prime}$-deoxyCMP and 2.9 units of the purified enzyme $\left(0.014 \mathrm{mg}\right.$ as protein) was incubated at $55^{\circ}$ for $1 \mathrm{hr}$.

(A) Pyrimidine $5^{\prime}$-ribonucleotides

- - $-5-\quad 5^{\prime}-\mathrm{UMP}-\mathbf{\Delta}-\triangle-5^{\prime} \mathrm{CMP}$

(B) Pyrimidine 5'-deoxyribonucleotides

$-\bullet-O-5^{\prime}$-deoxyUMP $-\Delta-\triangle-5^{\prime}$-deoxyCMP

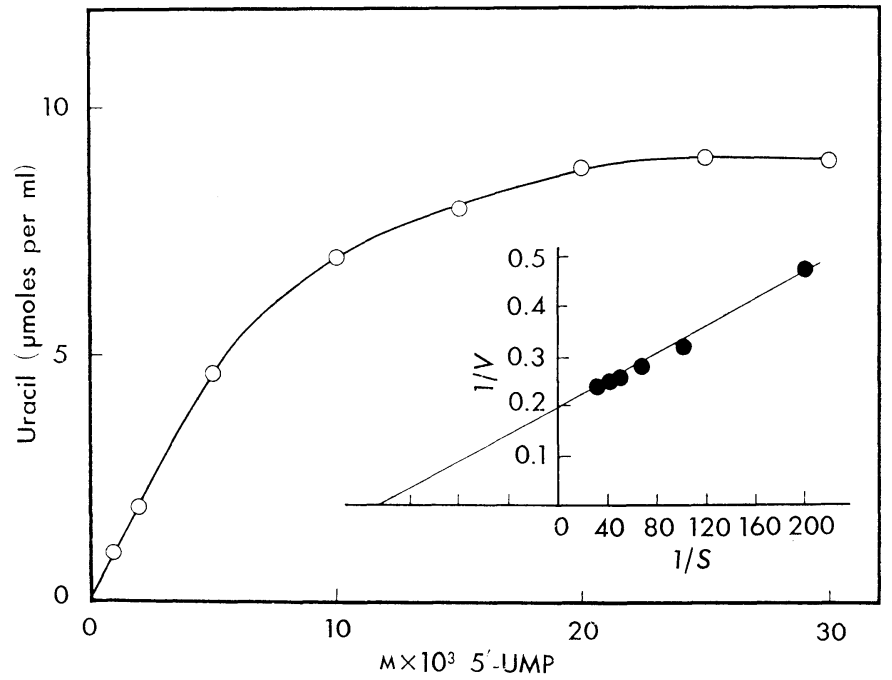

Fig. 3. Effect of substrate concentration on the rate of degradation.

One $\mathrm{ml}$ of the reaction mixture containing $200 \mu$ moles of acetate buffer ( $\mathrm{pH}$ 6.0), $1 \mu$ mole of $\mathrm{CaCl}_{2}, 11.7$ units of purified enzyme $(0.08 \mathrm{mg}$ as protein) and $5^{\prime}$-UMP as indicated was incubated at $55^{\circ}$ for $30 \mathrm{~min}$. 
Table 2. Effect of phosphate, pyrophosphate and ATP.

One $\mathrm{ml}$ of the reaction mixture containing $20 \mu$ moles of $5^{\prime}$-UMP, 100 $\mu$ moles of acetate buffer ( $\mathrm{pH} 6.0), 1 \mu$ mole of $\mathrm{CaCl}_{2}$, additions as indicated and 5.78 units of enzyme $\left(0.04 \mathrm{mg}\right.$ as protein) was incubated for $1 \mathrm{hr}$ at $55^{\circ}$.

\begin{tabular}{l|c|c}
\hline \multicolumn{1}{c}{ Addition } & Concn. $(\mathrm{mM})$ & $\begin{array}{c}\text { Uracil formed } \\
(\mu \text { moles per ml })\end{array}$ \\
\hline None & & 6.50 \\
$\mathrm{KH}_{2} \mathrm{PO}_{4}$ & 0.1 & 6.68 \\
& 0.5 & 6.75 \\
& 1.0 & 6.55 \\
& 2.5 & 6.80 \\
Na-pyrophosphate & 5.0 & 6.50 \\
& 0.1 & 6.75 \\
& 0.5 & 7.12 \\
ATP & 1.0 & 6.80 \\
& 2.5 & 3.85 \\
& 5.0 & 0.32 \\
& 0.1 & 6.50 \\
& 0.5 & 6.80 \\
& 1.0 & 6.50 \\
& 2.5 & 6.75 \\
& 5.0 & 6.68 \\
\hline
\end{tabular}

tates formed were centrifuged off and ammonium sulfate fractionation was carried out with the supernatant solution. The precipitates formed between ammonium sulfate saturation of 35 and $55 \%$ were collected and dissolved in $10.1 \mathrm{ml}$ of $20 \mathrm{~mm}$ acetate buffer $(\mathrm{pH} 6.0)$. Then this solution was loaded on a $2 \times 42 \mathrm{~cm}$ column of Sephadex G-100 and the column was washed with $20 \mathrm{mM}$ acetate buffer $(\mathrm{pH}$ 6.0). The enzyme was eluted following the main peak of protein. The filtered fractions with high specific activity were pooled and designated as "purified enzyme" (Table 1).

\section{$5^{\prime}$-UMP degradation by purified enzyme}

Fig. 1 illustrates the time course of the degradation of $5^{\prime}$-UMP by the purified enzyme. The formation of uracil, ribose-5-phosphate and reducing sugar corresponded in amount to each other. The formation of inorganic phosphate was negligible.

Effect of $p H$

Optimum $\mathrm{pH}$ for the degradation of every pyrimidine $5^{\prime}$-nucleotide was about 7 (Fig. 2). However, the shapes of the pH-activity curves were not exactly the same. $5^{\prime}$-CMP was degraded in a broader $\mathrm{pH}$ range as compared with other nucleotides. 
Table 3. Effect of various enzyme inhibitors and heavy metal ions.

One $\mathrm{ml}$ of the reaction mixture containing $20 \mu$ moles of $5^{\prime}$-UMP, $100 \mu$ moles of acetate buffer ( $\mathrm{pH}$ 6.0), additions as indicated and 5.2 units of enzyme $(0.6$ $\mathrm{mg}$ as protein) was incubated at $55^{\circ}$ for $80 \mathrm{~min}$.

\begin{tabular}{l|r|r}
\hline \multicolumn{1}{c|}{ Addition } & \multicolumn{2}{|c}{ Concentration } \\
\hline & $1 \mathrm{mM}$ & $10 \mathrm{mM}$ \\
\hline $\mathrm{None}$ & \multicolumn{2}{|c}{ per cent inhibition } \\
$\mathrm{NaF}$ & 0 & 0 \\
p-chloromercuribenzoate & -1.2 & -0.8 \\
$\mathrm{NaN}_{3}$ & 7.5 & 95.1 \\
$\mathrm{KCN}$ & -6.5 & 1.6 \\
$\mathrm{Na}_{2} \mathrm{HAsO}_{4}$ & 5.9 & 65.9 \\
$\mathrm{Na}_{2} \mathrm{HPO}_{4}$ & 2.5 & 10.0 \\
$\mathrm{CH}_{3} \mathrm{COOAg}$ & -0.5 & 15.6 \\
$\mathrm{HgCl}_{2}$ & 89.5 & 100.0 \\
$\mathrm{CuCl}_{2}$ & 39.4 & 92.7 \\
$\mathrm{ZnCl}_{2}$ & 83.6 & 94.2 \\
$\mathrm{CdCl}_{2}$ & 92.7 & 100.0 \\
$\mathrm{CrCl}_{3}$ & 84.3 & 100.0 \\
$\mathrm{EDTA}$ & -1.2 & 45.1 \\
\hline
\end{tabular}

\section{Effect of substrate concentration}

The $K_{m}$ value for $5^{\prime}$-UMP calculated from LINEWEAVER and BURK plot ( $\left.\boldsymbol{y}\right)$ was about $6.95 \times 10^{-3} \mathrm{M}$ (Fig. 3).

\section{Effect of phosphates}

Even by the use of " purified enzyme" preparation, the reaction proceeded without the addition of any co-factors. The activity was also unaffected by the removal of low molecular weight compounds by dialysis.

Addition of phosphate, pyrophosphate and ATP to the reaction mixture did not show any appreciable stimulation (Table 2). Pyrophosphate was inhibitory at high concentrations.

\section{Stability of enzyme}

The purified enzyme was stable at low temperatures at $\mathrm{pH}$ 6.0. After 1 week at $5^{\circ}$ or 2 months at $-4^{\circ}$, no loss of activity was noted. The activity in the crude extracts remained unchanged in buffers between $\mathrm{pH} 5.5$ and 8.8 at $65^{\circ}$ for $1 \mathrm{hr}$, and even at $75^{\circ} \pm 3^{\circ}$ the loss of the activity was within $10 \%$. However, the activity was completely lost within $2 \mathrm{~min}$ in a boiling water bath. The activity was unstable at $\mathrm{pH} 4.0$ above $37^{\circ}$. 
Table 4. Recovery of EDTA-inhibition by metal ions.

One $\mathrm{ml}$ of the reaction mixture containing $20 \mu$ moles of $5^{\prime}$-UMP, $100 \mu$ moles of acetate buffer ( $\mathrm{pH} 6.0$ ), $5 \mu$ moles of metal salts as indicated and the EDTAtreated enzyme $\left(0.38 \mathrm{mg}\right.$ as protein) was incubated at $55^{\circ}$ for $80 \mathrm{~min}$.

\begin{tabular}{l|c}
\hline \multicolumn{1}{|c|}{ Addition } & Uracil formed (umoles per ml) \\
\hline None & \\
None & $5.61^{a}$ \\
$\mathrm{KCl}$ & 0.42 \\
$\mathrm{MgCl}_{2}$ & 0.53 \\
$\mathrm{CaCl}_{2}$ & 2.67 \\
$\mathrm{BaCl}_{2}$ & 3.87 \\
$\mathrm{AlCl}_{3}$ & 3.11 \\
$\mathrm{SnCl}_{2}$ & 2.63 \\
$\mathrm{MnCl}_{2}$ & 2.82 \\
$\mathrm{FeCl}_{2}$ & 2.23 \\
$\mathrm{FeCl}_{3}$ & 1.91 \\
$\mathrm{CoCl}_{2}$ & 1.89 \\
$\mathrm{NiCl}_{2}$ & 1.08 \\
$\mathrm{CuCl}_{2}$ & 0.69 \\
$\mathrm{ZnSO}_{4}$ & 0.04 \\
\end{tabular}

a The reaction was carried out using the enzyme without EDTA treatment.

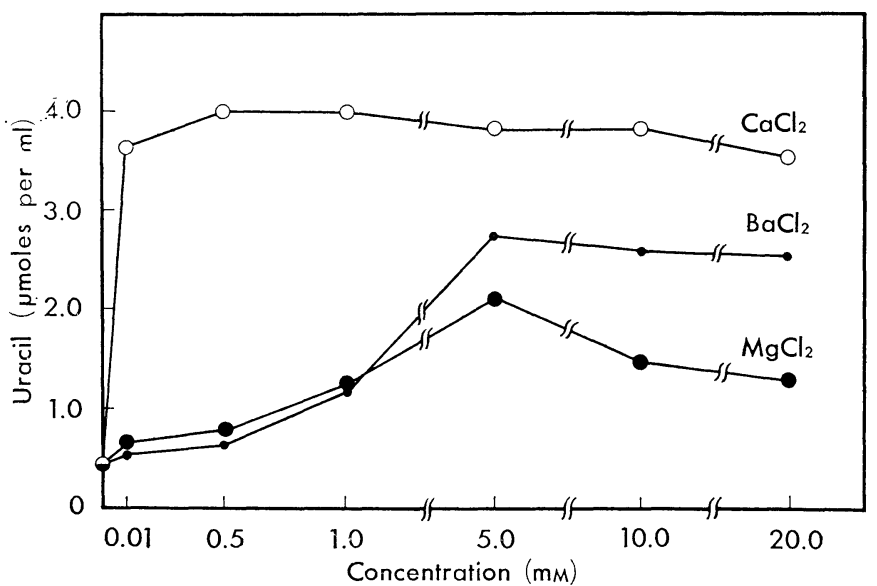

Fig. 4. The effect of $\mathrm{Ca}^{++}, \mathrm{Mg}^{++}$and $\mathrm{Ba}^{++}$at various concentrations.

One $\mathrm{ml}$ of the reaction mixture containing $20 \mu$ moles of $5^{\prime}$-UMP, $100 \mu$ moles of acetate buffer ( $\mathrm{pH} 6.0$ ) and metal ions as indicated and $0.38 \mathrm{mg}$ as protein of the EDTA-treated enzyme was incubated for $90 \mathrm{~min}$ at $55^{\circ}$. 


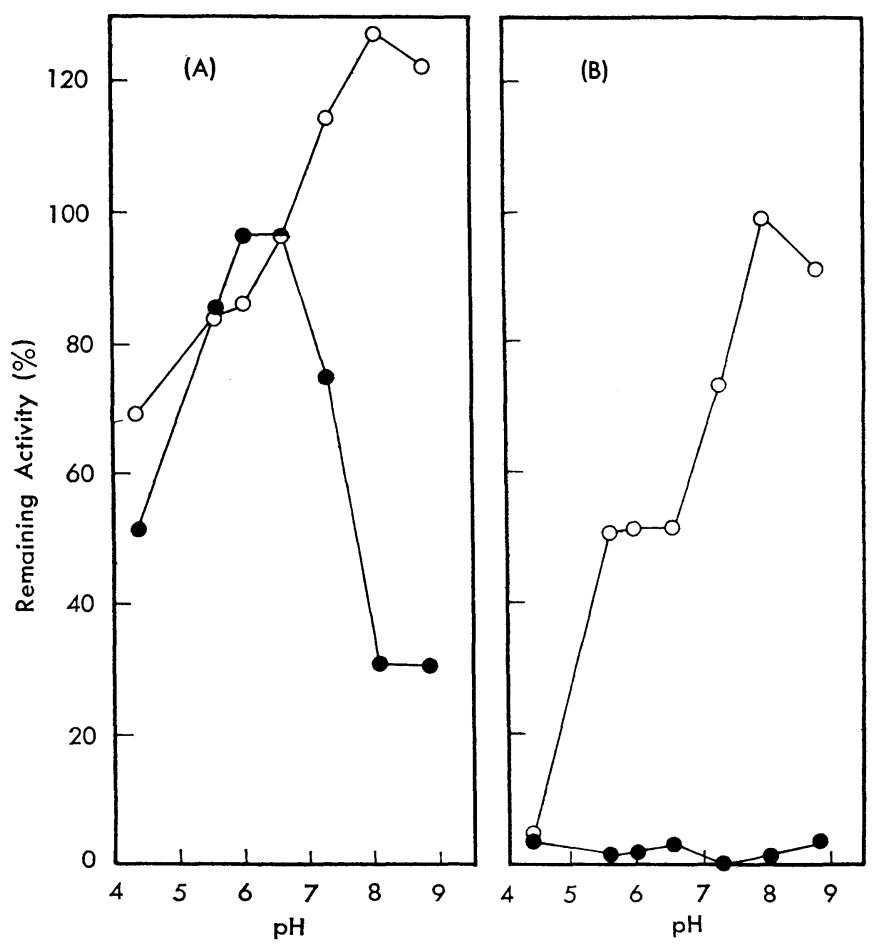

Fig. 5. Effect of $\mathrm{Ca}^{++}$on the stability of enzyme.

The EDTA-treated enzyme was incubated with and without added $0.5 \mathrm{mM} \mathrm{CaCl}_{2}$ at (A) $22^{\circ}$ and (B) $65^{\circ}$ for 45 minutes in $10 \mathrm{~mm}$ buffers of varying $\mathrm{pH}$. Buffers used were acetate buffer (below $\mathrm{pH} 6.0$ ) and Tris acetate buffer (above pH 6.6). The remaining activity was examined in the assay system containing $5 \mathrm{~mm} \mathrm{CaCl}_{2}$.

$$
\text { -O- with } \mathrm{CaCl}_{2} \quad-\bullet-\text { without } \mathrm{CaCl}_{2}
$$

Effect of some enzyme inhibitors and metal ions

The presence of SH-residue in the enzyme is suggested by the inhibition of $p$-chloromercuribenzoate and the requirement of metal ions is supposed by the inhibition of EDTA and KCN. Some heavy metal ions were inhibitory for the degradation. (Table 3).

To find out the required metal ions, the reaction was carried out using the EDTA-treated enzyme with and without the presence of metal ions. As indicated in Table 4, the activity lost during the EDTA-treatment was restored by a variety of metal ions, such as $\mathrm{Mg}^{++}, \mathrm{Ca}^{++}, \mathrm{Ba}^{++}, \mathrm{Al}^{+++}, \mathrm{Sn}^{++}, \mathrm{Mn}^{++}$, $\mathrm{Fe}^{++}, \mathrm{Fe}^{+++}$and $\mathrm{Co}^{++}$. Then the effect of $\mathrm{Mg}^{++}, \mathrm{Ca}^{++}$and $\mathrm{Ba}^{++}$was examined at various concentrations (Fig. 4). Of these three metal ions, $\mathrm{Ca}^{++}$was found to be most effective in recovering the activity, especially at very low concentrations. 


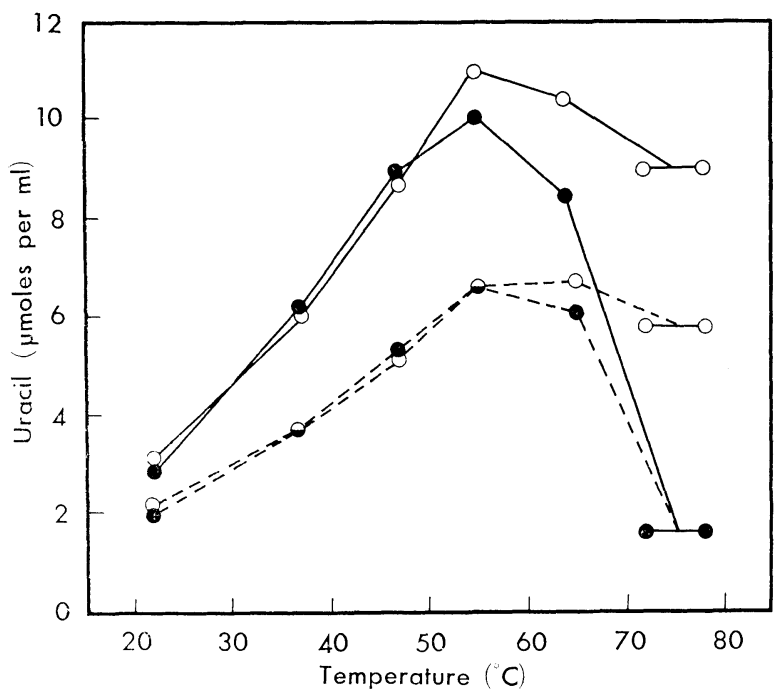

Fig. 6. Effect of $\mathrm{Ca}^{++}$on the reaction at various temperatures.

See text for the reaction system. Amount of enzyme used was 6.25 units (corresponding to $0.75 \mathrm{mg}$ protein) per $\mathrm{ml}$ of the reaction mixture.

-- - $1 \mathrm{hr}$ incubation with $1 \mathrm{~mm} \mathrm{CaCl}_{2}$

- $\mathrm{O}-2 \mathrm{hr}$ incubation

- without $\mathrm{CaCl}_{2}$

Effect of $\mathrm{Ca}^{++}$

The thermostability of the EDTA-treated enzyme was tested with and without the addition of $\mathrm{Ca}^{++}$(Fig. 5). In the absence of $\mathrm{Ca}^{++}$, the activity was significantly lost even at $22^{\circ}$ at $\mathrm{pH}$ range lower and higher than 6.0 and 6.5. However, the enzyme became very stable with added $\mathrm{Ca}^{++}$, especially at $\mathrm{pH}$ 8.0. At this $\mathrm{pH}$, the activity remained unchanged by the treatment at $65^{\circ}$ for $45 \mathrm{~min}$. Moreover, it is noteworthy that the activity was increased by the exposure of the EDTA-treated enzyme to $\mathrm{Ca}^{++}$at $22^{\circ}$.

On the other hand, the effect of $\mathrm{Ca}^{++}$on the reaction rate of the EDTAtreated enzyme was examined. As depicted in Fig. 6, the rate of the reaction was unaffected by $\mathrm{Ca}^{++}$at temperatures below $47^{\circ}$. The reaction proceeded even at such high temperature as $75^{\circ}$ when $\mathrm{Ca}^{++}$was added.

These data suggest that $\mathrm{Ca}^{++}$takes part in the stability of the enzyme activity rather than in the reaction itself, though the latter possibility has not entirely been excluded.

\section{Substrate specificity}

The substrate specificity was studied with three enzyme preparations: (A) crude extracts of 1-day culture cells, (B) crude extracts of 4-day culture cells and $(\mathrm{C})$ purified enzyme from (B). The rate of the hydrolysis of the $\mathrm{N}$-glycosidic linkage was determined by the appearance of reducing activity. 
Table 5. The substrate specificity of the enzyme.

Various nucleotides and nucleosides were incubated with (A) enzyme extracted from 1-day culture cells, (B) crude extracts shown in Table 1 and with (C) purified enzyme. Five units of the enzyme was put in $1 \mathrm{ml}$ of the reaction mixture and incubated at $55^{\circ}$ for $2 \mathrm{hr}$.

The rate of the reaction was estimated spectrophotometrically (S) or by the appearance of reducing activity $(R)$. Relative rates based on $5^{\prime}$-UMP are also indicated.

\begin{tabular}{|c|c|c|c|c|c|c|c|c|}
\hline \multirow[b]{3}{*}{ Substrate } & \multirow{3}{*}{$\begin{array}{l}\text { Concn. } \\
\text { tested } \\
(\mu \text { moles } \\
\text { per ml })\end{array}$} & \multirow[b]{3}{*}{ Assay } & \multicolumn{6}{|c|}{ Enzyme preparation } \\
\hline & & & \multicolumn{2}{|c|}{ A } & \multicolumn{2}{|c|}{$\mathrm{B}$} & \multicolumn{2}{|c|}{$\mathrm{C}$} \\
\hline & & & $\begin{array}{c}\text { Hydro- } \\
\text { lysis } \\
\text { ( } \mu \text { moles } \\
\text { per ml) }\end{array}$ & $\begin{array}{l}\text { Rela- } \\
\text { tive } \\
\text { rate }\end{array}$ & $\begin{array}{c}\text { Hydro- } \\
\text { lysis } \\
(\mu \mathrm{moles} \\
\text { per ml) }\end{array}$ & $\begin{array}{l}\text { Rela- } \\
\text { tive } \\
\text { rate }\end{array}$ & $\begin{array}{l}\text { Hydro- } \\
\text { lysis } \\
\text { ( } \mu \text { moles } \\
\text { per ml) }\end{array}$ & $\begin{array}{l}\text { Rela- } \\
\text { tive } \\
\text { rate }\end{array}$ \\
\hline \multirow[t]{2}{*}{$5^{\prime}-\mathrm{UMP}$} & 16.8 & $\mathrm{~S}$ & 8.48 & & 8.74 & & 9.11 & \\
\hline & & $\mathrm{R}$ & 8.60 & 100 & 8.56 & 100 & 9.56 & 100 \\
\hline \multirow[t]{2}{*}{$5^{\prime}-\mathrm{CMP}$} & 16.8 & S & 5.36 & & 6.63 & & 7.76 & \\
\hline & & $\mathrm{R}$ & 5.25 & 73 & 6.21 & 73 & 7.36 & 77 \\
\hline $5^{\prime}$-deoxyUMP & 17.9 & $\mathrm{R}$ & 6.99 & 81 & 6.80 & 79 & 7.11 & 74 \\
\hline $5^{\prime}$-deoxyCMP & 16.6 & $\mathrm{R}$ & 4.97 & 58 & 4.84 & 57 & 6.06 & 64 \\
\hline $5^{\prime}$-deoxyTMP & 14.9 & $\mathrm{R}$ & 6.52 & 76 & 6.25 & 73 & 7.06 & 74 \\
\hline $5^{\prime}-\mathrm{AMP}$ & 16.8 & $\mathrm{R}$ & $-b$ & - & 0.06 & - & - & - \\
\hline $5^{\prime}-\mathrm{GMP}$ & 16.0 & $\mathrm{R}$ & 1.00 & 12 & 1.59 & 19 & 0 & 0 \\
\hline $5^{\prime}-\mathrm{IMP}$ & 16.0 & $\mathrm{R}$ & 0.75 & 9 & 0.70 & 8 & 0 & 0 \\
\hline $5^{\prime}-\mathrm{XMP}$ & 18.4 & $\mathrm{R}$ & - & - & 1.59 & - & - & - \\
\hline $5^{\prime}$-deoxy AMP & 17.3 & $\mathrm{R}$ & - & - & 1.01 & - & - & - \\
\hline $5^{\prime}$-deoxyGMP & 16.6 & $\mathrm{R}$ & - & - & 1.70 & - & - & - \\
\hline $3^{\prime}-\mathrm{UMP}$ & 20.0 & $S \cdot R$ & - & - & 0 & 0 & 0 & 0 \\
\hline $\mathrm{UDP}^{a}$ & 16.0 & S & - & - & - & - & $0.5^{a}$ & 0 \\
\hline UTP & 16.0 & $\mathrm{~S}$ & - & - & - & - & 0 & 0 \\
\hline Uridine & 16.0 & $\mathrm{~S} \cdot \mathrm{R}$ & - & - & 0 & - & 0 & - \\
\hline $\begin{array}{l}2^{\prime} \text {-O-methyl- } \\
5^{\prime} \text {-UMP }\end{array}$ & 5.0 & $\mathrm{~S} \cdot \mathrm{R}$ & - & - & 0 & - & - & - \\
\hline
\end{tabular}

For 5'-UMP and 5'-CMP, the assay was also performed by spectrophotometric method.

As indicated in Table 5 , pyrimidine $5^{\prime}$-nucleotides were strongly degraded. Although purine $5^{\prime}$-nucleotides were hydrolyzed by the crude extracts, they were not hydrolyzed by the purified enzyme. This finding suggests the presence of another enzyme which specifically attacks purine $5^{\prime}$-nucleotides.

By paper electrophoresis, the degradation of both purine and pyrimidine $5^{\prime}$-nucleotides was found to result in the formation of their corresponding bases. 
In any case, the formation of nucleosides was never detected.

Uridine and $3^{\prime}$-UMP, as well as nucleosides and $3^{\prime}$-nucleotides of other bases, were completely resistant to the reaction. When $2^{\prime}$-hydroxy residue of $5^{\prime}$-UMP was methylated, i.e. $2^{\prime}-0$-methyl-5'-UMP, the compound became inert as substrate. UDP and UTP were not degraded.

The substrate specificity of the enzyme extracted from Streptomyces hygroscopicus was analogous to that of the enzyme from Streptomyces virginiae.

\section{Examination of reverse reaction}

The reaction mixture containing $2 \mu$ moles of uracil, $10 \mu$ moles of ribose5 -phosphate, $100 \mu$ moles of acetate buffer $(\mathrm{pH} 6.0)$ or Tris buffer $(\mathrm{pH} 8.0)$, $1 \mu$ mole of $\mathrm{CaCl}_{2}, 2 \mu$ moles of $\mathrm{MgCl}_{2}$ and 24 units of the purified enzyme in a total volume of $1 \mathrm{ml}$ was incubated at $37^{\circ}$. The reaction was stopped at 5 min intervals by heating the solution in a boiling water bath for 5 min. The formation of $5^{\prime}$-UMP from uracil was estimated spectrophotometrically by the decrease of optical density at $290 \mathrm{~m} \mu$. No shift of optical density occurred during the reaction period of $1 \mathrm{hr}$.

The reaction was carried out also using 5-phosphoribosyl-1-pyrophosphate and ribose-1-phosphate. However, the formation of $5^{\prime}$-UMP or uridine was never detected in any case.

\section{DISCUSSION}

This enzyme, "pyrimidine 5'-nucleotide phosphoribo (deoxyribo) hydrolase", hydrolyzes the N-glycosidic linkage of pyrimidine $5^{\prime}$-nucleotides (Scheme 1).

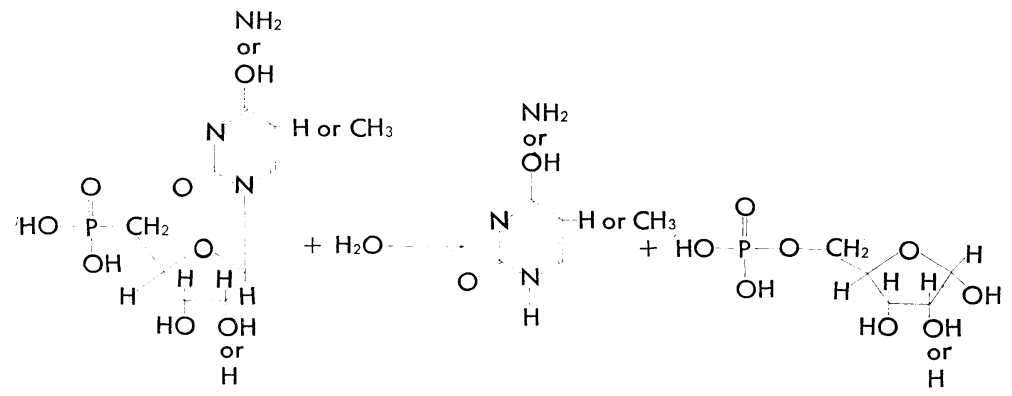

Scheme 1. Pyrimidine 5'-nucleotide phosphoribo (deoxyribo) hydrolase.

The reverse reaction has not been demonstrated.

Since the relative rates of the hydrolysis of $5^{\prime}$-UMP, $5^{\prime}$-CMP, $5^{\prime}$-deoxyUMP, $5^{\prime}$-deoxyCMP and $5^{\prime}$-deoxyTMP (relative values based on the hydrolysis of $5^{\prime}$-UMP $=100$, Table 5) by the crude enzyme preparation extracted from 1 day culture cells, 4-day culture cells, and by the 31-fold purified enzyme were almost the same, a single enzyme was presumed to be responsible for the degradation of different pyrimidine $5^{\prime}$-nucleotides. This assumption will be 
verified by further purification of the enzyme.

Co-factors of low molecular weight, including phosphate, pyrophosphate and ATP, are unnecessary for the reaction. Therefore the involvement of phosphorolytic or pyrophosphorolytic process seems improbable and the Nglycosidic linkage in pyrimidine $5^{\prime}$-nucleotides is supposed to be cleaved in a hydrolytic manner.

This enzyme seems to be a kind of metal enzyme. Like $\alpha$-amylases from various sources, this enzyme is markedly stabilized by the presence of $\mathrm{Ca}^{++}$.

As compared with the hitherto known pathways of the degradation of pyrimidine nucleotides (Scheme 2, right half), the pathway afforded by the present enzyme (Scheme 2, left half) is quite different.

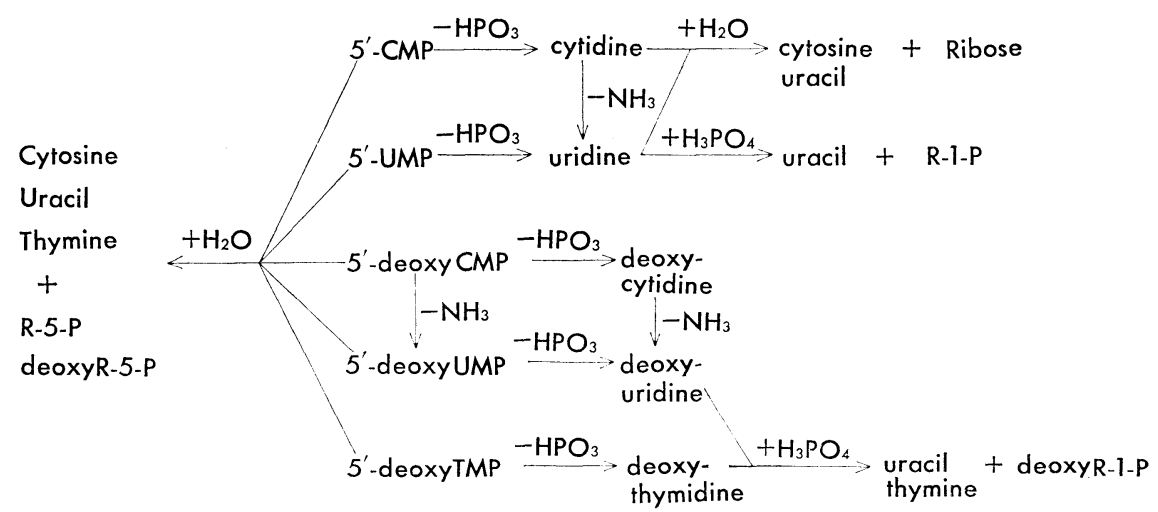

Scheme 2. Degradation pathways of pyrimidine nucleotides.

Though it is not described in detail in the present report, another enzyme, which catalyzes the hydrolysis of purine $5^{\prime}$-nucleotides to purine bases and pentose phosphates, is found in cell-free extracts of Streptomyces. Studies on this enzyme are in progress.

The author is indebted to Dr. R. Takeda and Mr. Y. Ishida of our laboratories for their interest and encouragement during the course of this investigation. The author wishes to thank Dr. M. Yoneda and Dr. S. Igarasi for their helpful discussion and advice in preparing this manuscript.

\section{REFERENCES}

1) A. Imada, M. Kuno and S. Igarasi: J. Gen. Appl. Microbiol., I3, 247 (1967).

2) P. E. Plesner and H. Klenow: In Methods in Enzymology, ed. by S. P. Colowick and N. O. Kaplan, Vol. III, Academic Press, N.Y. (1957), p. 181.

3) A. Imada, I. Nogami and S. Igarasi: Annual Rept. Takeda Res. Labs., 25, $55,(1966)$.

4) A. H. Brown: Arch. Biochem., 11, 269 (1946).

5) M. Somogyi: J. Biol. Chem., 160, 61 (1945); 195, 19 (1952).

6) A. Imada, Y. Nakao and K. Ogata: Agr. Biol. Chem., 26, 611 (1962).

7) H. Lineweaver and D. Burk: J. Am. Chem. Soc., 56, 658 (1934). 